Cite this: Indo. Chim. Acta., 2020, 13, 1.

Received Date: 27th May 2020 Accepted Date: 18th June 2020

\section{Impact of Cyclone on Livelihood Pattern in the South Western Coastal Region of Bangladesh: Pirojpur}

\author{
Dilara Nasrin ${ }^{1}$, Mahmuda Binte Latif ${ }^{1}$, Shamim Al Mamun ${ }^{1 *}$, Reyad Hossain Arif ${ }^{1}$ and \\ Muliadi2 $^{2}$
}

\begin{abstract}
This research was carried out to assess the impact of cyclone on livelihood pattern in Pirojpur district, Bangladesh during January to June, 2017. The study was both qualitative and quantitative type. The primary data were collected using randomly sampling method $(42+42+42=126$ respondents) from Tushkhali, Bhitabaria and Pattashi villages of Pirojpur district. The secondary data were collected from different journals, articles, books, official documents, thesis papers and also daily newspapers etc. From the study it was observed that monthly income of middle (4001-8000 tk) and high (8001-above tk) income groups ware decreased by $5 \%$ and $0.92 \%$ respectively while low income people (1-4000 tk) was increased due to decrease of production after Sidr. On the other hand, expenditure ability of low and middle income groups was decreased. Sidr has created a great impact on human health, livestock, fisheries, food habit, crop production and occupation pattern of the affected people. Respondent's houses were damaged partially (66.78\%), 33.22\% completely and cultivated land $28.57 \%$ completely by Sidr in study area. Respondents of the study area said that the production of rice $(8 \%)$, chili $(12 \%)$, and vegetables $(11 \%)$ were reduced due to saline water entrance into the crop field after Sidr. Affected people were migrated (temporary $23.10 \%$, local $25 \%$ and internal $26.10 \%$ ) from Pirojpur to Dhaka (53\%), Pirojpur to other places (47\%) on the post Sidr due to loss of houses, shelters, cultivated land and lack of job opportunity. Among all factors of temporary migration, water logging was the first reason of migrating people of the study area.
\end{abstract}

\section{Introduction}

Bangladesh is currently ranked as one of the world's foremost disaster-prone country. Due to its unique (Delta) geographic position, Bangladesh is one of the most climate vulnerable countries on earth. The much acclaimed Stern Review (2007) narrates that Bangladesh will be one of the most vulnerable countries in the world due to climate change. The review also describes that both sea level rise and climate change would force many more to leave their homelands in the future (Stern, 2007). Bangladesh suffers from frequent natural hazards including tropical cyclones and storm surges, river and coastal flooding, landslides and droughts. But the inhabitants of coastal areas of Bangladesh

${ }^{1}$ Department of Environmental Science and Resource Management, Mawlana Bhashani Science and Technology University, Tangail-1902, Bangladesh: shamim084du@gmail.com

2Department of Chemistry, Universitas Khairun, Ternate, Maluku Utara, Indonesia are more exposed to specific hazards such as coastal flooding, cyclones and tsunami, among which cyclone and induced surges are the most recurrent natural hazard (Wisner et al., 2004).

The people of this area lose their lives and livelihoods disproportionately, homes and lands, damage to infrastructure and economic assets due to the tropical cyclones. From 1990 to 2007, Bangladesh faced several deadly cyclones, causing death of 150,000 people and displacing millions (Climate Change Cell, 2007). Many people migrate from their inherited land to another due to cyclone, coastal flooding, and storm surge in southern part of Bangladesh. Myers (2001) estimated that Bangladesh alone would produce 26 million climate refugees in the future. This situation may cause many problems like accommodation, food, other necessary needs and increase 
poverty of hosting areas.

Pirojpur is a coastal and more environmental disasters prone district situated at the Southern part of our country. It stands on the bank of river Bolesshor. The people of this district perceive different disaster like cyclone, coastal flooding every year. But a devastating tropical cyclone Sidr occurred on 15 November 2007 and created massive loss of lives and economy of this district which people could not recovery that losses. The present study explores the impact of cyclone (Sidr) on livelihood pattern of Pirojpur, coastal area of Bangladesh as a case. The specific objectives of the study were to assess the livelihood conditions of the affected people of the study area, to investigate how the people coped with in respond to cyclone in that area and to explore the trend and pattern of migration in Pirojpur.

\section{Experimental}

\section{Material and Methods Study Area}

The study was conducted in three villages (Tushkhali, Bhitabaria and Pattashi) of Mathbaria, Bhandaria and Indurkani upazila respectively under Pirojpur district which were located in $22^{\circ} 24^{\prime} \mathrm{N}$ latitude to $90^{\circ} 03^{\prime} \mathrm{E}$ longitude, $22^{\circ} 33^{\prime} \mathrm{N}$ latitude to $90^{\circ} 08^{\prime} \mathrm{E}$ longitude and $22^{\circ} 32 \mathrm{~N}$ latitude to $90^{\circ} 03^{\prime} \mathrm{E}$ longitude respectively. Total households of Tushkhali village were 3997, Pattashi were 6377 and Bhandaria were 5625 (BBS, 2011). Studied three coastal villages of Pirojpur District are more disaster prone areas of Bangladesh have suffered heavy loss in crops, lives, livelihoods and property by different disasters like, Aila, Sidr etc. in different years (Figure 1).

\section{Method of data collection}

Both quantitative and qualitative techniques of data collection were used for this study. The research was carried out on the bases of primary and secondary data. Among all households of Tushkhali, Bhitabaria and Pattashi villages, total $126(42+42+42)$ respondents were selected using random sampling method to collect primary data. The sample size was calculated by the following equation (n), = z2.p.q.N/e2 (N-1) +z2.p.q (Source: Kothari, 1990).

For Tushkhali village of Mathbaria upazilla, respondents was 42 where, Population of Error (e) $=10 \%=0$, Confidence level $=90 \%$, at confidence level $90 \%$ the Value of $\mathrm{z}$ at $90 \%(\mathrm{z})=1.29$, Population $(\mathrm{N})=3997$, absence of target population $(\mathrm{p})=50 \%=0.5, \mathrm{q}=1-\mathrm{P}=(1-0.5)=0.5$, Thus for Bhitabaria of Bhandaria upazila and Pattashi of Indurkani upazila, the sample size was 42,42 respectively. The household survey was carried out by sequential openended and close ended questionnaires and personal interviews of the selected respondents. Besides these, key informant interviews of local authorities and NGO's and FGD were also conducted for primary data collection. Relevant secondary data and information were collected from annual reports, official statistics, official regulation, grey literature and journal articles, governmental and nongovernmental official documents and statistics, yearly reports, various books, research papers, journals, maps, daily newspapers etc. to fulfil the objectives of the study.

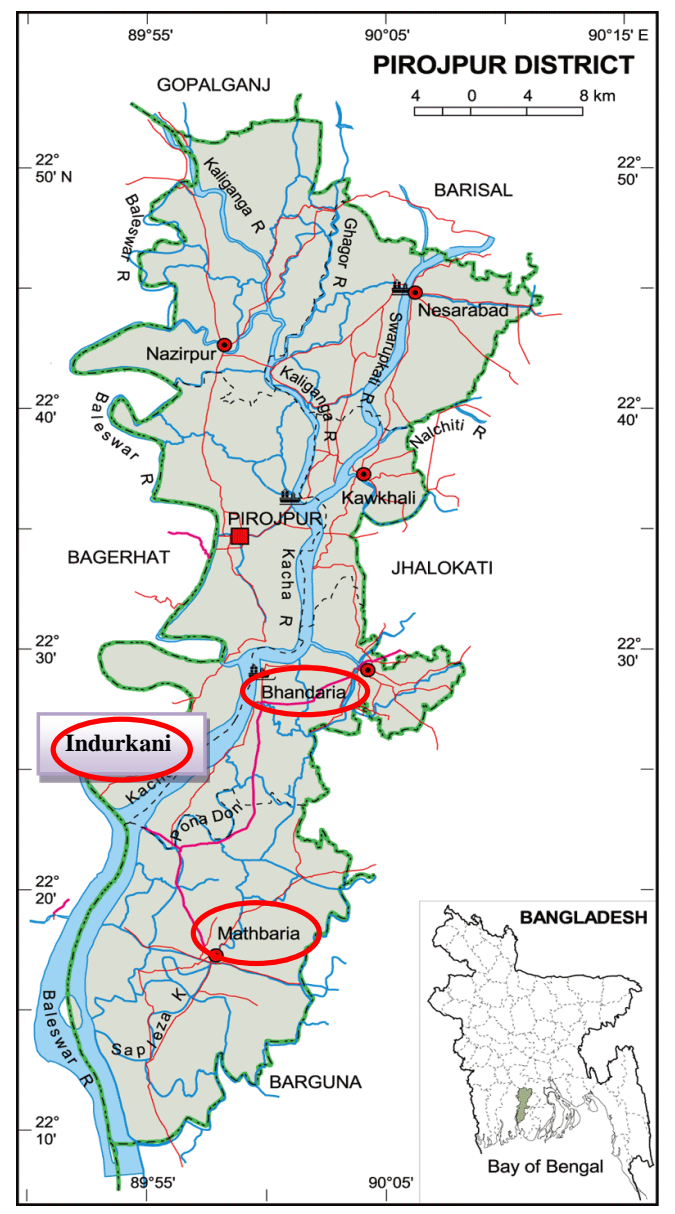

Figure 1. Map showing the location of Study area $\bigcirc$ (Source: Banglapedia, 2008)

\section{Result and Discussion}

\section{Demographic Data of the Respondents}

A total of 126 respondents were interviewed randomly of within $58 \%$ were male and rest were female. It is revealed that $25 \%$ respondents were within $18-28$ age groups, $42 \%$ were $29-39$ age, and $22 \%$ were $40-50$ age group in the study area. Major portion $38 \%$ of the respondents were illiterate, $33 \%$ of Primary level passed, $19 \%$ were secondary and only $9 \%$ were college level passed in the study area. 


\section{House Structure and Location of the Respondents}

Most of the houses (71\%) of the study area were kaccha. The semi pacca were $16 \%$, pacca $9 \%$ and jhupri $3 \%$. The Survey also shows that most of the houses were either near river bank (45\%) that were subject to destroy by flood or in the disaster prone areas (35\%) or island $(12 \%)$ and rest of them were in seashore.

\section{Present Household's Occupation Type}

Most of the respondents (37\%) of the study area lived their livelihood on agriculture. $34 \%$ and $14 \%$ of the respondents were engaged in day labour and business respectively. $12 \%$ respondents were engaged in service and rest of them were in industry or others.

\section{Monthly Income Ranges of the Respondents}

According to the findings, among all the respondents $38.32 \%$ had income range (1-4000 tk), while 50\% were (4001-8000tk) income group and the rest of were within income ranges (8001-above tk).

\section{Impact of Cyclone on Livelihood Pattern}

Monthly Income and expenditure changes of the respondents

The amount of income has been automatically influenced by the changes of occupation pattern which was influenced by Sidr in study area. Consequently, low income group (1$4000 \mathrm{tk}$ ) was increased on post Sidr in that area. Before Sidr $38.32 \%$ people earned a lowest amount of money. But after Sidr, the lowest income group was $44.24 \%$. Again, the middle income group (4001-8000 tk) was decreased after Sidr in that area (Table 1). After Sidr, monthly expenditure of the lower and middle expenditure groups ware decreased in the study area. Lower expenditure group was changed from $57 \%$ to $52 \%$ after Sidr. But high expenditure group was increased by $12 \%$ to $23 \%$ after Sidr due to repair and reconstruct of their houses and other structures.

Table 1: Monthly Income and expenditure changes of the respondents before and after Sidr (Source: Field Survey, 2017).

\begin{tabular}{|c|c|c|c|}
\hline & \multirow[b]{2}{*}{ Items } & \multicolumn{2}{|c|}{ Respondents (\%) } \\
\hline & & Pre Sidr (before 2007) & Post Sidr (2017) \\
\hline \multirow{3}{*}{ 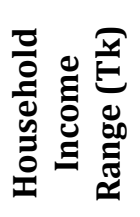 } & 1-4000 tk (Low Income Group) & 38.32 & 44.24 \\
\hline & 4001-8000 tk(Middle Income Group) & 50 & 45 \\
\hline & 8001-above tk (High Income Group) & 11.68 & 10.76 \\
\hline \multirow{3}{*}{ 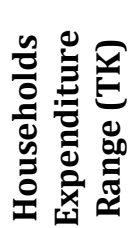 } & 1-4000 tk (Low Expenditure Group) & 57 & 52 \\
\hline & 4001-8000tk (Middle expenditure Group) & 31 & 25 \\
\hline & 8001-above tk (High Expenditure Group) & 12 & 23 \\
\hline
\end{tabular}

\section{Changes of Occupation Pattern}

During the post Sidr, the occupation of the affected people significantly changed due to shortage of capital, loss of livestock, low employment opportunity. Most of them had to migrate for their occupation. After Sidr, majority (36\%) of the respondents were adopted in non-agricultural day labor work than the pre-Sidr (16\%). Non-agricultural day labor includes rickshaw pulling, fishing, hawkering, construction work etc. Agricultural day labor work reduced from $56 \%$ to $32 \%$ in post- Sidr period (Figure 2)

\section{Impact on Respondent's Health}

After Sidr majority of the respondent were suffering from dysentery (43\%), diarrhoea (24\%) and other diseases (33\%) which include Jaundice, fever, skin diseases, fever, flu cough etc.

\section{Food Habit Change}

From the study it was observed that respondents had to reduce their daily meal like taking rice $(7 \%)$, fish $(10 \%)$, fruits $(6 \%)$, vegetables $(5 \%)$, meat $(1 \%)$, egg $(5 \%)$ gradually due to insufficient income and reduction of income opportunity after Sidr, but they had to take more flour (37\%) then the pre Sidr (Figure 3). 


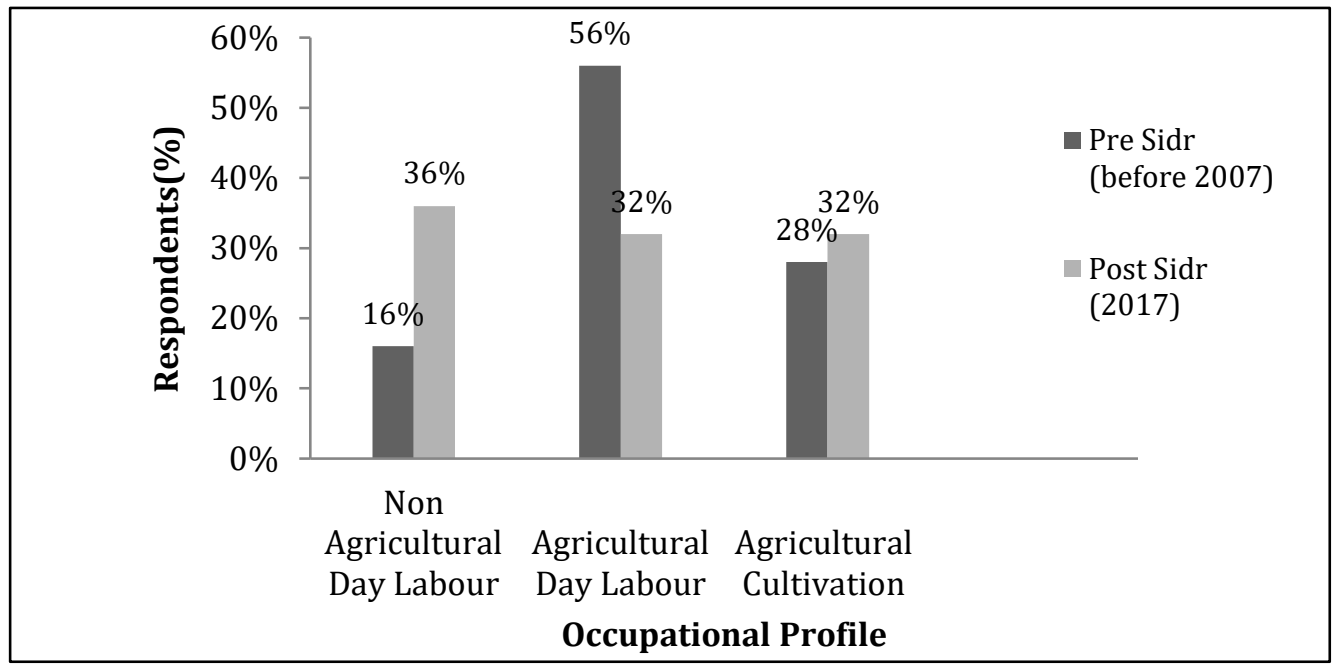

Figure 2. Changes of Occupation due to Sidr (Field Survey, 2017)

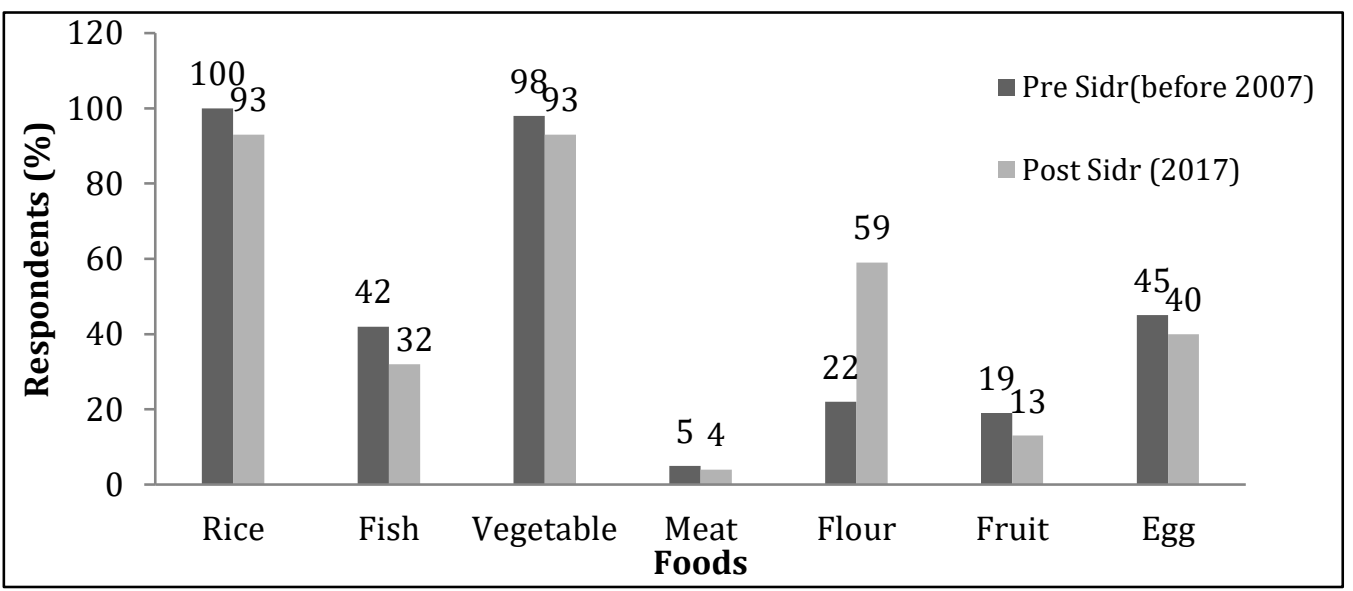

Figure 3. Changes of Food Habit due to Sidr (Source: Field Survey, 2017).

\section{Types of Damage Occurred}

All respondents were lost their property as well as damaged their livelihood pattern partially or completely. About $66.78 \%$ respondent's houses were damaged partially and $33.22 \%$ completely.

Table 2: Types of Damage (Partially or Completely) Occurred in Study Area (Source: Field Survey, 2017).

\begin{tabular}{ccc}
\hline \multirow{2}{*}{ Types of Damage } & \multicolumn{2}{c}{ Respondents (\%) } \\
\cline { 2 - 3 } & Partially & Completely \\
\hline House & 66.78 & 33.22 \\
\hline Tree Falling & 76.19 & 23.81 \\
\hline Cultivated Land & 71.43 & 28.57 \\
\hline Drinking Water Sources & 69.84 & 30.16 \\
\hline Road & 91.27 & 8.73 \\
\hline Embankment & 87.30 & 12.69 \\
\hline Cyclone Shelter & 00 & 00 \\
\hline
\end{tabular}

Thus tree falling, cultivated land, drinking water sources, roads, cyclone shelter and embankment were damaged partially and completely in remarkable amount (Table 2).

\section{Damages of Crop Production}

The tidal surge created a significant impact on the production of different crops like rice, chili, pulse, vegetables, betel nut and coconut. Respondents of the study area said that the production of rice (8\%), chili $(12 \%)$, and vegetables $(11 \%)$ were reduced due to saline water entry into the crop field after Sidr. But 22\% respondents stated that the production of pulse was increased in post Sidr due to increase sedimentary land and low cost production practice of Pulse in study area (Figure 4). Betel nut was almost same in production.

\section{Livestock damages}

Most of the damages of livestock sector were caused by the tidal surge. Livestock damage data were collected from 
selected 126 respondents of the study area. During post cows $15.22 \%$ and goats were reduced to $17.41 \%$ (Figure 5 ). Sidr, the chickens were reduced to $12.27 \%$, ducks $29.91 \%$,

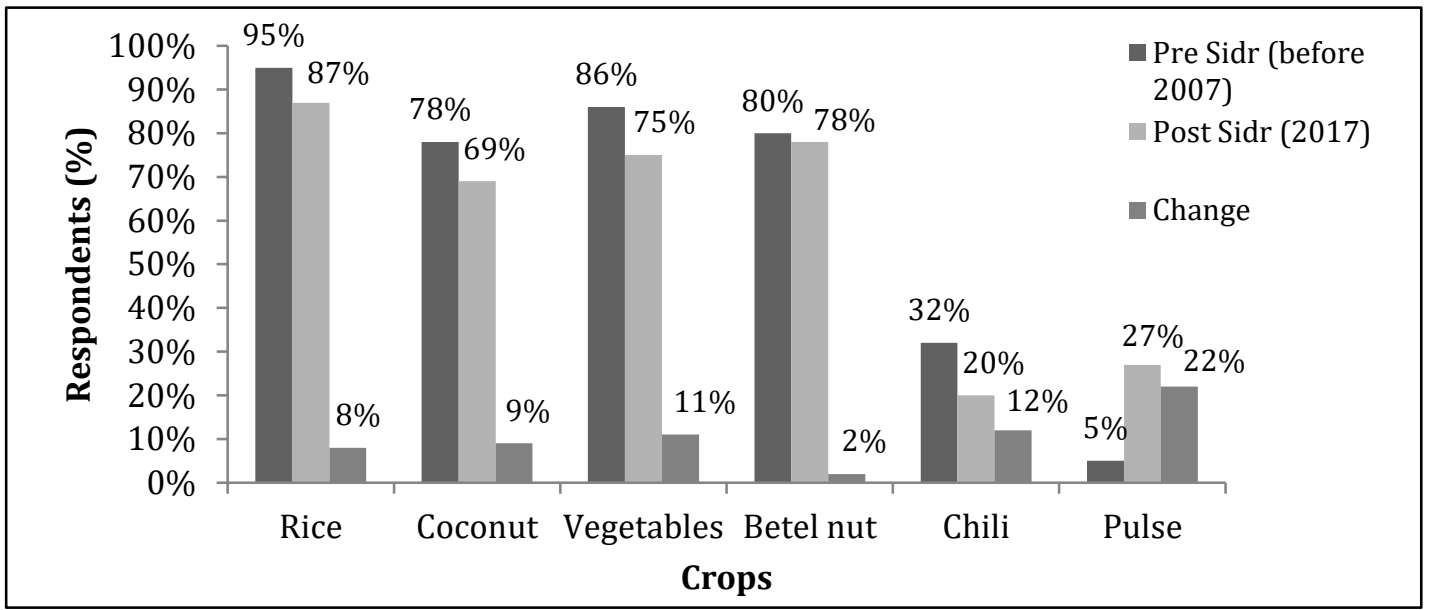

Figure 4. Changes in Crop Production due to Sidr (Source: Field Survey, 2017).

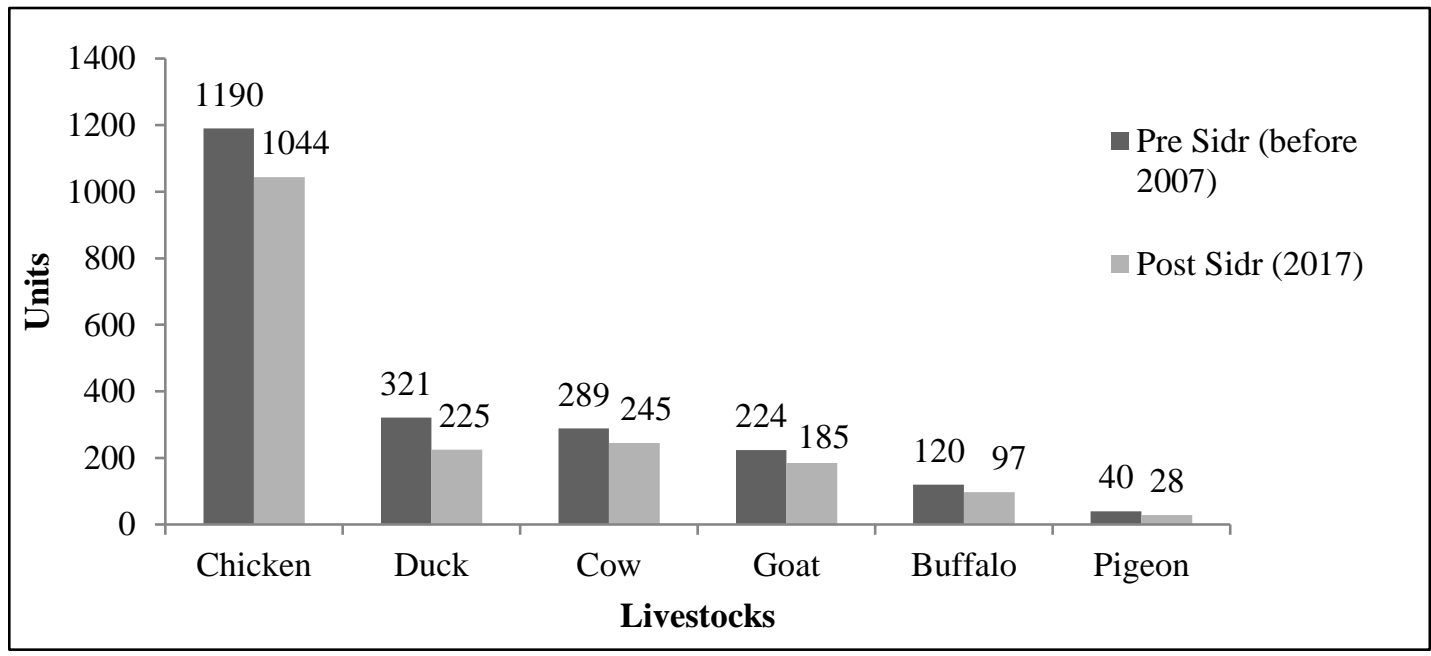

Figure 5. Damages of Livestock during Sidr (Source: Field Survey, 2017).

\section{Impact on Drinking Water}

Respondents did not collect their drinking water from the river before Sidr but it was $10 \%$ after Sidr due to damage their tube well by tidal surge. Collecting drinking water from ponds was also increased (13\%) after Sidr. Majority (97\%) of the respondents collected drinking water from tube well before Sidr but it was reduced by $23 \%$ after Sidr.

\section{Status of Public and Private Support on Post Sidr}

Table 3. clearly shows that maximum $(35.02 \%)$ of the respondent received their food from Non-Government Organization (NOGs) (35.02) than Government of Bangladesh (GoB) (25.83\%). About 20.58\% respondent met food by themselves, about $15.25 \%$ of the respondents replied that they managed it from the relatives and 3.32\% respondent said that they managed it from other sources. To meet the crisis of cash money, $15.85 \%$ of the respondent said that they got it from the GoB, $58.25 \%$ of them replied they got it from the NGO's, $22.75 \%$ of the respondent said that they had own to meet it, $2.50 \%$ of the respondent replied that they got it from the relatives and other source $0.66 \%$. Majority of the respondents got drinking water (45.83\%), cloths $(55.25 \%)$ and shelter $(48.85 \%)$ from NGO's and 50\% respondent took support of drinking water, $22.5 \%$ cloths and $27.25 \%$ shelter from GoB. They got minimum help from other sources. Maximum (48.33\%) respondents received house materials from NonGovernmental Organization than Government of Bangladesh subsidies. About $16.66 \%$ respondents claimed that they built new house using their own money on post Sidr. In case of fishing boat and net, GoB supported $17.12 \%$ respondents to buy boat but support was zero to buy net after Sidr in the study area. But in case of NGOs, support was high to buy fishing boat, net and cattle (Table 3). 
Table 3. Government and private support during the post Sidr period

(Source: Disaster Management Bureau (DMB) office of Pirojpur, 2017).

\begin{tabular}{lccccc}
\hline \multirow{1}{*}{ Primary Needs } & \multicolumn{5}{c}{ Respondents (\%) } \\
\cline { 2 - 6 } & GoB & NGOs & Personal & Relatives & Others \\
\hline Money & 15.85 & 58.24 & 22.75 & 2.50 & 0.66 \\
\hline Food & 25.83 & 35.02 & 20.58 & 15.25 & 3.32 \\
\hline Water & 50.00 & 45.83 & 4.17 & 0.00 & 0.00 \\
\hline Cloth & 22.5 & 55.25 & 22.25 & 0.00 & 0.00 \\
\hline Shelter & 27.25 & 48.85 & 23.9 & 0.00 & 0.00 \\
\hline House Materials & 35 & 48.33 & 0.00 & 16.66 & 0.00 \\
\hline Fishing Boat & 17.12 & 47.44 & 0.00 & 35.44 & 0.00 \\
\hline Fishing Net & 0.00 & 84.00 & 0.00 & 0.00 & 16.00 \\
\hline Cattle & 8.13 & 48.54 & 0.00 & 43.33 & 0.00 \\
\hline
\end{tabular}

Table 4 : Trend of People's Migration due to Cyclone During Pre and Post Sidr

(Source: Disaster Management Bureau office of Pirojpur and Field Survey, 2017)

\begin{tabular}{lcc}
\hline Trend of Migration & $\begin{array}{c}\text { Time } \\
\text { (Pre-Sidr before 2007, } \\
\text { Post-Sidr 2017) }\end{array}$ & Respondents (\%) \\
\hline Pirojpur to Dhaka & Pre-Sidr & 35 \\
\cline { 2 - 3 } & Post-Sidr & 53 \\
\hline Pirojpur to Other Places & Pre-Sidr & 40 \\
\cline { 2 - 3 } & Post-Sidr & 47 \\
\hline Pirojpur to Abroad & Pre-Sidr & 25 \\
\cline { 2 - 3 } & Post-Sidr & 0 \\
\cline { 2 - 3 }
\end{tabular}

\section{Migration Pattern of Pirojpur}

From the study it is found that people migrated from Pirojpur to Dhaka (53\%) in the post Sidr while it was 35\% in pre Sidr due to loss of houses, shelters, cultivated land and lack of job opportunity. The migration from Pirojpur to other places was increased $47 \%$ than the pre-Sidr (40\%). The other place complies nearest district where they could find place to live, working opportunity and presence of relatives (Table 4).

\section{Types of Migration Occurred in the Study Area}

Migration due to cyclone, disaster or environmental change can be classified according to the extent of movement and the possibility of return. Based on those aspects, migration of the studied peoples can be classified in five categories, forced, temporary, local, and internal and vulnerability induced migration. In response to this question, people replied multiple answers. Summarized answers were like, forced contributed $16.10 \%$, temporary $23.10 \%$, local and internal migration covers $25 \%$ and
$26.10 \%$ respectively (Figure 6).

NOTE: (Forced Migration: Whose house structure was broken, damaged and unsuitable for living,Vulnerable: Similar to forced but houses were damaged fully, no way to live in there, Local: People shifted within Upazila and stayed there for long time, Internal: People shifted to nearest distance, either relatives house or shelter but stayed short time, Temporary: People shifted shelter but returned their houses within 1 day)

\section{Displacement Time of the Respondents}

People displaced to different locations within one week or a month. Migration actually started before cyclone affects the area. The survey shows that $84 \%$ people migrated to different places within 7 days after Sidr while $12 \%$ migrated between 8-14 days. Another $8 \%$ and $4 \%$ moved to different locations within 3rd week and 4th week respectively after the cyclone. Only $2 \%$ people migrated after one month. There were some extremely poor people tried to sustain in the affected areas due to lack of money. 


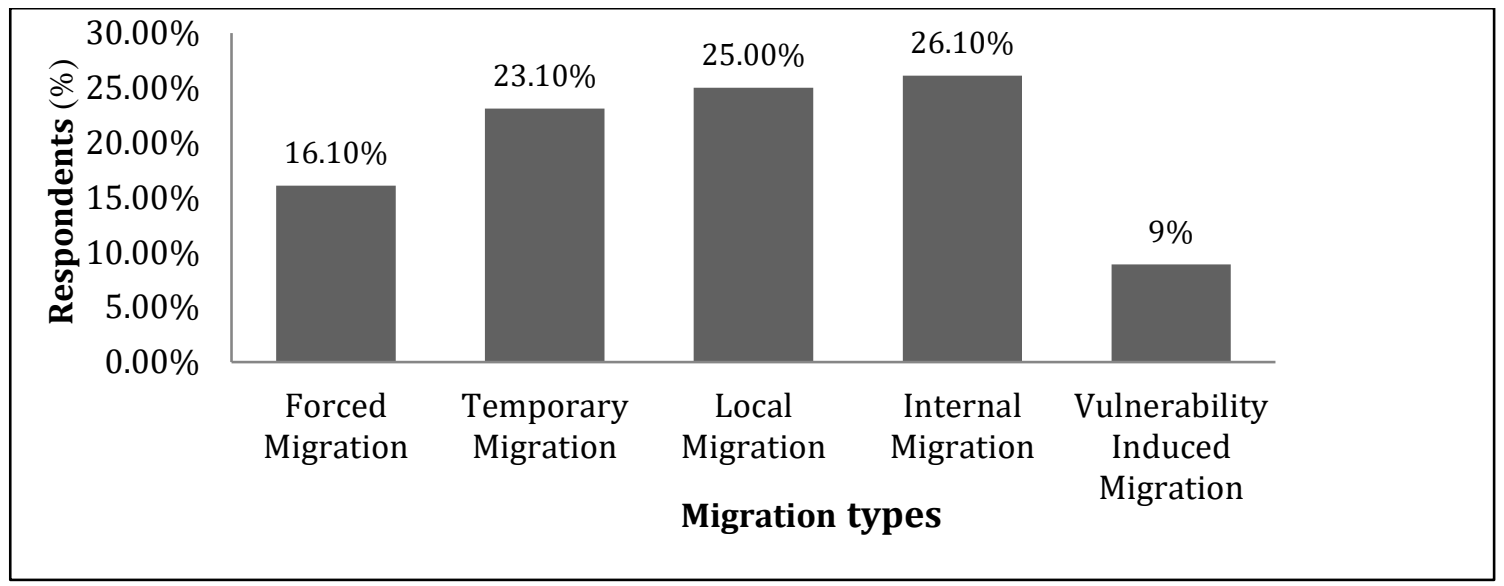

Figure 6. Migration Types in the study area (Source: Field Survey, 2017).

\section{Factors of Temporary Migration}

In the study area, there were some factors that influenced temporary migration of the respondents from native area. Among the factors, water logging caused $60.31 \%$ respondent's temporary migration which was the first reason of respondents to migrate. The loss of houses and shelters also caused peoples displacement which was the second reason of migration. Other factors like loss of cultivated lands, very few opportunity of work, lack of food $\&$ water were the $3 \mathrm{rd}, 4$ th and 5 th reason to migrate people temporarily from one place to another (Table 5).

Table 5: Factors of Temporary Migration in Study Area (Source: Field Survey, 2017).

\begin{tabular}{ccc}
\hline Factors & Respondents (\%) & Rank \\
\hline Water Logging & 60.31 & 1 \\
\hline Loss of Houses and Shelters & 16.67 & 2 \\
\hline Loss of Cultivated lands & 10.31 & 3 \\
\hline Very few opportunity of work & 6.35 & 5 \\
\hline Lack of Food \& Water & 3.17 & 6 \\
\hline Salinity Intrusion & 1.58 & 7 \\
\hline Violence of women & 1.00 & 8 \\
\hline Others & 0.61 &
\end{tabular}

Table 6: Returning Factors of Temporary Migrated People (Source: Field Survey, 2017).

\begin{tabular}{ccc}
\hline Returning Factors & Respondents (\%) & Priority \\
\hline Reduced Water Logging & 24.60 & 1 \\
\hline Opportunity of Work & 18 & 2 \\
\hline Food Availability & 15 & 3 \\
\hline Become NGO Beneficiary & 12.7 & 4 \\
\hline House Support from Govt./NGO & 11 & 5 \\
\hline Agriculture Started & 10 & 6 \\
\hline Physical Safety & 8.7 & 7 \\
\hline
\end{tabular}

\section{Returning Factors of Temporary Migrated People}

Many families displaced from their houses due to several reasons but came back when the condition became improve to live in their village. $24.60 \%$ respondent reported that they returned their houses as the water logging situation had become improve which was the first priority of returning home. Other factors like Opportunity of work, Food availability, become NGO beneficiary were the $2 \mathrm{nd}$, 3rd and 4th priority of the respondents to return their houses or native area. A good number of people had become NGO's beneficiary as many recovery programmes were started by different NGOs in the cyclone affected area (Table 6). 


\section{Conclusion}

Almost every year coastal people experience damage of assets, crops, poultry, livestock, houses as well as livelihoods by cyclone, coastal flooding, tidal surge, coastal erosion and so on. According to the Bangladesh bureau of statistics 2011, Mathbaria, Indurkani, Bhandaria Upazilas are the area of greatest impact as far as the percentage of total affected population is concerned. The living standard, average income and expenditure of the respondents were decreased due to decrease of production after Sidr. Sidr has created a great impact on crops, livestock, fisheries, food habit and profession of the affected people. All of the respondents were lost their properties as well as damaged their livelihood partially or completely. To meet their primary needs they were depended on the support of NGO's, GoB and other organizations. The migration rate of Sidr affected area was increased. People were being forced to migrate from this coastal area to other places like nearest place, within district, Dhaka or other places in order to improve their chances to make a living.

\section{Acknowledgement}

Special appreciation to Shofiqul Islam, Upazilla Project Implementation Officer, Disaster Management Bureau Department, Indurkani; Md. Abdul Latif, Assistant Director of Cyclone Preparedness Programme (CPP), Mathbaria; Md. Ansar Ali, UD, District Administrator Office, Relief and Rehabilitation Branch; Ajit Chandra Hawladar, JSO, Bangladesh Bureau of Statistics (BBS) Department, Mathbaria; Md. Faizul Islam, Project Implementation Officer, Mathbaria; Md. Moazzem Hossain Hawladar, Chairman of Pattashi Union Parishad, Indurkani, Pirojpur for their constructive advices and suggestions during the research work.

\section{References}

Ahmed, A.U., Hasan, S.R., Etzold, B., \& Neelrom, S. 2012. Rainfall, food security, and human mobility: case study Bangladesh. UNUEHS Report 2. UNU-EHS, Bonn.

Alam, S., 2003. Environmentally Induced Migration from Bangladesh to India. Strategic Analysis 27(3): 422-438.
Alam, M.R., 2012. Climate change and its impact on health and livelihood within Hatiya Island of Bangladesh. J. Agro for. Environ. 6 (2), 13-16.

Adger, W. N., Hughes, T. P., Folke,C., Carpenter, S. R., \& Rockström, J., 2005. Social-Ecological Resilience to Coastal Disasters, Science 309 (5737), 1036-1039. [doi: 10.1126/science.1112122]

Banglapedia, 2008. National Encyclopedia of Bangladesh, Asiatic Society of Bangladesh, Dhaka, Bangladesh

BBS, 2011. Report on Bangladesh Population Census 2011, Bangladesh Bureau of Statistics, Statistics Division, Ministry of Planning, Government of the People's Republic of Bangladesh, Dhaka.

Climate Change Cell, 2007. The Government of Bangladesh. Retrieved from: http://www.climatechangecell-bd.org.

DMB, 2010. National Plan for Disaster Management 2010- 2015. Disaster Management Bureau, Peoples Republic Government of Bangladesh. Dhaka, 114.

DMB, 2010. Standing Orders on Disaster, Ministry of Food and Disaster Management, Disaster Management \& Relief Division, Disaster Management Bureau. Dhaka, Bangladesh, April 2010.

IPCC, (2007). Climate change 2007: Synthesis report. Intergovernmental Panel on Climate Change, Geneva.

Kothari, C, R., 1990. Research Methodology, 2nd Edition, New Age International (P) limited, India. P. 179.

Myers, Norman. 2001. Environmental Refugees: a growing phenomenon of the 21st Century. Philosophical Transactions of the Royal Society B: 356:16.1-16.5.

Mahbub, A. Q. M., 1997. Mobility behaviour of working people in Bangladesh. Urban Studies Forum (USP), Department of Geography and Environment, University of Dhaka

Stern, Nicholas, 2007. The Economics of Climate Change: The Stern Review. Cambridge University Press: Cambridge.

Wisner, B., P. Blakie, T. Cannon \& I. Davies., 2004. At Risk. Routledge, London and New York. 